\title{
High Foam Phenotypic Diversity and Variability in Flocculant Gene Observed for Various Yeast Cell Surfaces Present as Industrial Contaminants
}

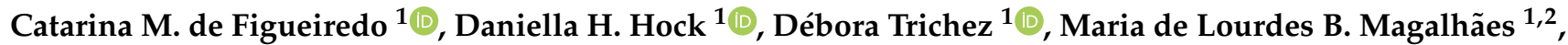 \\ Mario L. Lopes ${ }^{3}$ (D), Henrique V. de Amorim ${ }^{3}$ and Boris U. Stambuk ${ }^{1, *(D)}$
}

check for

updates

Citation: de Figueiredo, C.M.; Hock, D.H.; Trichez, D.; Magalhães, M.d.L.B.; Lopes, M.L.; de Amorim, H.V.; Stambuk, B.U. High Foam Phenotypic Diversity and Variability in Flocculant Gene Observed for Various Yeast Cell Surfaces Present as Industrial Contaminants. Fermentation 2021, 7, 127. https:// doi.org/10.3390/fermentation7030127

Academic Editor: Diomi Mamma

Received: 29 June 2021

Accepted: 19 July 2021

Published: 24 July 2021

Publisher's Note: MDPI stays neutral with regard to jurisdictional claims in published maps and institutional affiliations.

Copyright: (c) 2021 by the authors. Licensee MDPI, Basel, Switzerland. This article is an open access article distributed under the terms and conditions of the Creative Commons Attribution (CC BY) license (https:/ / creativecommons.org/licenses/by/ $4.0 /)$.
1 Center of Biological Sciences, Department of Biochemistry, Federal University of Santa Catarina, Florianópolis 88040-900, SC, Brazil; catfigueiredo@gmail.com (C.M.d.F.); daniellahock@hotmail.com (D.H.H.); debora_trichez@yahoo.com.br (D.T.); maria.magalhaes@udesc.br (M.d.L.B.M.)

2 Center of Agroveterinary Sciences, Biochemistry Laboratory, Department of Food and Animal Production, State University of Santa Catarina, Lages 88520-000, SC, Brazil

3 Fermentec, Av. Antonia Pazinatto Sturion 1155, Piracicaba 13420-640, SP, Brazil; mario@fermentec.com.br (M.L.L.); amorim@fermentec.com.br (H.V.d.A.)

* Correspondence: boris.stambuk@ufsc.br; Tel.: +55-48-3721-4449

\begin{abstract}
Many contaminant yeast strains that survive inside fuel ethanol industrial vats show detrimental cell surface phenotypes. These harmful effects may include filamentation, invasive growth, flocculation, biofilm formation, and excessive foam production. Previous studies have linked some of these phenotypes to the expression of FLO genes, and the presence of gene length polymorphisms causing the expansion of $F L O$ gene size appears to result in stronger flocculation and biofilm formation phenotypes. We performed here a molecular analysis of FLO1 and FLO11 gene polymorphisms present in contaminant strains of Saccharomyces cerevisiae from Brazilian fuel ethanol distilleries showing vigorous foaming phenotypes during fermentation. The size variability of these genes was correlated with cellular hydrophobicity, flocculation, and highly foaming phenotypes in these yeast strains. Our results also showed that deleting the primary activator of FLO genes (the FLO8 gene) from the genome of a contaminant and highly foaming industrial strain avoids complex foam formation, flocculation, invasive growth, and biofilm production by the engineered (flo8 $:: B l e^{\mathrm{R}} /$ flo8 $\left.8:: k a n M X\right)$ yeast strain. Thus, the characterization of highly foaming yeasts and the influence of FLO8 in this phenotype open new perspectives for yeast strain engineering and optimization in the sugarcane fuel-ethanol industry.
\end{abstract}

Keywords: foam; flocculation; FLO genes; Saccharomyces; fuel-ethanol; FLO8

\section{Introduction}

The renewable Brazilian sugarcane first-generation fuel-ethanol industry is highly competitive, when compared with ethanol production processes from other crops (e.g., corn and sugarbeet), as it shows the highest percentage of greenhouse gas emissions' reduction, highest energy balance and yields per hectare, and the lowest production costs [1,2]. The productivity of the Brazilian fuel ethanol industry has increased steadily since 1975, an increase possibly due to several improvements, including the selection of new sugarcane varieties with an increased amount of sugarcane biomass per hectare and also the amount of ethanol produced from each ton of sugarcane, as the industrial sector responsible for this, including the fermentation process, has also reached high industrial efficiency [3-5].

In Brazil, over $70 \%$ of the milling and distilling companies perform the Melle-Boinot process, a fed-batch fermentation with high cell density that allows higher production stability when compared to the continuous mode [6,7]. At the end of each fermentation, the yeast cells are centrifuged, treated with diluted sulphuric acid, and over $90 \%$ of the yeast cells are reused from one fermentation to the next to ensure the high cell density 
that contributes to very short fermentation times and, thus, the high productivity of the process $[3,5,8]$. However, as many industrial processes, the substrate (sugarcane juice and/or diluted molasses) is not sterile and, thus, a continuous input of contaminant microorganisms is observed $[9,10]$. While lactic acid bacteria are contaminants of concern in industrial ethanol fermentations [11,12], wild yeasts also affect the productivity of these fermentations, leading to decreased efficiency and stuck fermentations that cause plants to shut down for cleaning before beginning a new fermentation [13-16].

Saccharomyces cerevisiae is the predominant microorganism responsible for the efficient production of fuel ethanol [17], and studies of the microbiological dynamics of the industrial fermenters revealed a very rapid succession of yeast strains during fuel ethanol fermentations and, consequently, the original starter yeast (usually a commercial baker's yeast strain) is completely replaced by other strains in a matter of weeks [18-21]. Nevertheless, some yeast strains tend to dominate the fermenters, allowing the selection of suitable industrial strains with high fermentative capacity and viability to withstand the stressful industrial conditions, which includes high temperatures and osmotic pressures, high ethanol concentrations, low nutrients and $\mathrm{pH}$, and process interruptions, to mention some stresses $[4,19,22,23]$. Another highly desired characteristic for the yeast cells used in this industrial process is that cells need to be in an unicellular planktonic state to allow efficient centrifugation for cell recycling, avoiding other operational problems (e.g., clogging, stuck/sluggish fermentations) that are a consequence of structured multicellular lifestyles (biofilms, premature/excessive flocculation) that this microorganism may adopt $[19,24,25]$.

Another cell-surface phenotype, intensive foam formation, is also of great concern as highly foaming yeast strains do not allow the use of the fermenter total volume capacity, decreasing productivity and increasing costs due to the use of antifoam agents $[3,19,26,27]$. Moreover, it has been recently shown that industrial antifoam agents impair ethanol fermentation and decrease yeast cell viability, inducing a clear stress response in an industrial strain under conditions that simulate the Brazilian sugarcane-based ethanol production process with cell recycling [28]. While foam formation and stability are important in some fermented beverages like sparkling wines and beer $[29,30]$, excessive foam production during fuel-ethanol fermentation is undesirable. Foam accumulates at the air-liquid interface and is the consequence of a complex process where $\mathrm{CO}_{2}$ bubbles absorb a series of compounds (cells, proteins, carbohydrates, polyphenols, ions, and surfactants), which influence foam production and maintenance. Yeast glycoproteins present in the cell wall may be released during fermentation and, while their hydrophobic proteinaceous domains can interact with air bubbles, their hydrophilic mannose polysaccharides are exposed to the aqueous medium, contributing to foam formation and stabilization [30-32]. Approaches to stabilize beer foam include decreasing the secretion of proteinase A by the yeast cells, a protease known to hydrolyze proteins important for foam stability $[33,34]$. Yeast cells with a highly hydrophobic cell wall can also attach to $\mathrm{CO}_{2}$ bubbles, contributing to the production of stable and rigid foams $[35,36]$.

All these different phenotypic lifestyles that $S$. cerevisiae cells adopt are the consequence of the expression of specific cell-wall proteins that mediate cell-cell as well as cell-environment interactions $[37,38]$. The most important yeast proteins involved in yeast flocculation, biofilm formation, invasive growth, and other cell surface phenotypes are the adhesins or flocculins encoded by the FLO gene family. The genome of $S$. cerevisiae contains several telomeric FLO genes encoding for flocculins (e.g., FLO1, FLO5, FLO9, and FLO10), the FLO11 gene (also called MUC1) located in the sub-telomeric region of chromosome IX, and the transcriptional activator FLO8 located in the right arm of chromosome $\mathrm{V}$ [37-39]. Several studies have identified the FLO1 and FLO11 gene products as major participants in yeast cell-surface processes [40]. These adhesins belong to a large family of fungal cell-wall glycoproteins that usually share only a low degree of primary amino acid sequence similarity, but have a common overall architecture consisting of at least three different domains. The N-terminal domain that follows the secretion signal peptide is exposed at the cell surface and confers the recognition and binding of ligand molecules, a 
middle domain that contains many tandem repeats extremely rich in serine and threonine (and also proline) residues that is highly glycosylated, and a C-terminal domain were the glycosylphosphatidylinositol (GPI) anchor is added for localizing the adhesins to the cell surface, although the adhesins may also be covalently linked to the non-reducing end of $\beta-1,6$-glucans of the cell wall via a GPI remnant [38,41,42].

The N-terminal domain differs significantly between FLO11 and the other flocculin genes. The structure of the N-terminal domain of the flocculin encoded by FLO11 (Pfam entry PF10182, https:/ / pfam.xfam.org, accessed on 20 May 2020) is composed of three subdomains, including a hydrophobic apical region, a $\beta$-sandwich of the fibronectin type III domain, and the neck subdomain [43]. Two aromatic bands (containing tryptophan and tyrosine residues) that are present at the ends of the adhesion domain mediate homotypic and hydrophobic adhesion to a range of solid surfaces and the air-liquid interface of flor (or velum) in sherry-like wine fermentations [42-46]. The N-terminal domain of the other flocculins (e.g., FLO1 or FLO5) have a lectin-like structure (PA14 domain, Pfam entry PF07691) that binds (in a $\mathrm{Ca}^{2+}$-dependent manner) to mannose oligosaccharides present in the yeast cell surface $[42,47,48]$. Consequently, FLO11 and the other FLO genes play distinct roles in adhesion, flocculation, invasive growth, biofilm formation, and other cell surface phenotypes of yeast cells $[40,49]$. A further level of complexity is determined by the serine/threonine-rich middle domain, which contains intragenic tandem repeats of DNA sequences that trigger recombination, causing variations in gene size, and the expansion of this middle domain contributes to stronger flocculation, biofilm formation, and other cell surface phenotypes of yeast cells $[39,50,51]$.

The first yeast gene described as specifically involved in foam formation was the AWA1 gene, encoding for a cell-wall GPI-linked and highly glycosylated serine/threoninerich protein from sake-producing yeasts [52]. As with FLO genes, the serine/threonine-rich domain in $A W A 1$ can also vary in size, contributing to different foaming phenotypes of sake yeasts [53,54]. More recently, primers based in the AWA1 gene allowed the identification of two other highly homologous genes, the FPG1 gene responsible for foam formation in a wine yeast strain [55] and the CFG1 gene involved in foam production by S. pastorianus lager brewing yeasts [56].

In the present report, we analyzed several cell-surface properties (flocculation and cellwall hydrophobicity, foam and biofilm production, invasive growth) of a group of 15 wild and indigenous yeast strains isolated from sugarcane industrial fuel-ethanol production plants, including strains with good or bad (e.g., premature flocculation, excessive foam production) industrial characteristics. We also determined gene length polymorphisms in some adhesin genes (FLO1 and FLO11) and analyzed possible correlations with the phenotypic diversity found in this group of contaminant industrial yeast strains. Finally, we showed that a highly foaming industrial fuel-ethanol yeast strain loses its capacity to produce foam when this FLO8 gene is deleted, indicating that the expression of flocculins is involved in problematic (abundant and persistent) foam formation during industrial fermentation by this contaminant $S$. cerevisiae yeast.

\section{Materials and Methods}

\subsection{Strains, Media, and Growth Conditions}

The S. cerevisiae industrial strains studied were isolated during fuel ethanol production in Brazilian distilleries [19] and included two reference strains (CAT-1 and PE-2) widely used by many distilleries [23,57,58], as well as 13 strains (BAT-1, FT278, FT279, FT281, FT517, FT540, FT645, FT697, FT699, FT705, FT714, FT718, FT859) with reported premature flocculation/sedimentation and/or intensive foam production during industrial fuel-ethanol production [19]. The laboratory strains S288C (MAT $\alpha$ mal gal2 mel flo1 flo8-1 hap1 SUC2) and CEN.PK2-1C (MATa MAL2-8c ura3-52 his3D1 leu2-3_112 trp1-289) were also used for mutant construction and amplification of probes for Southern analysis. Yeasts were cultivated on YPD medium ( $2 \%$ peptone, $1 \%$ yeast extract, and $2 \%$ glucose) or molasses-based medium containing $20 \mathrm{~g} / \mathrm{L}$ total sugars from sugarcane molasses, $0.5 \%$ 
yeast extract, $0.5 \%\left(\mathrm{NH}_{4}\right)_{2} \mathrm{SO}_{4}$, and $0.2 \% \mathrm{KH}_{2} \mathrm{PO}_{4}$. When required, 0.3 or $2 \%$ agar and $200 \mathrm{mg} / \mathrm{L}$ geneticin (G-418) sulfate (Invitrogen, Thermo Fisher Scientific Inc., Sinapse Biotecnologia, São Paulo, SP, Brazil) or $100 \mathrm{mg} / \mathrm{L}$ zeocin (Invivogen, San Diego, CA, USA) were added to the medium. Cells were grown aerobically at $28^{\circ} \mathrm{C}$ with shaking $(160 \mathrm{rpm})$ in cotton-plugged Erlenmeyer flasks filled to $1 / 5$ of the volume with medium.

\subsection{Foam Quantification}

Yeast cells were cultivated in rich YPD medium until $1 \pm 0.5 \mathrm{~g}$ (dry cell weight, $\mathrm{DCW}) / \mathrm{L}$, harvested by centrifugation $(7.000 \times g, 5 \mathrm{~min})$ and washed twice with cold, sterile water. A cellular suspension of $10 \mathrm{~g}$ DCW/L was prepared in $5 \mathrm{~g} / \mathrm{L} \mathrm{Na}_{2} \mathrm{SO}_{4}$ and added to molasses-based medium (final sugar and other components' concentrations as indicated above), incubated at room temperature under constant agitation (100 rpm) during $8 \mathrm{~h}$, and foam formation was volumetrically monitored during the fermentation. Foam formation was expressed as the percentage of foam volume in relation to the fermentation media volume.

\subsection{Flocculation Tests}

To test cell-cell adhesion, flocculation assays were performed based on the protocol described by Wang et al. [59]. Cells were grown in molasses medium until the late exponential growth phase $(3 \pm 0.5 \mathrm{~g} \mathrm{DCW} / \mathrm{L})$, harvested by centrifugation, and washed twice with $50 \mathrm{mM}$ sodium citrate, $50 \mathrm{mM}$ EDTA, and pH 3.0 buffer, followed by two washings with cold, distilled water. After centrifugation, cells were suspended (5 g DCW/L) in $100 \mathrm{mM}$ sodium acetate, $\mathrm{pH} 4.0$ buffer, and their ability to flocculate in the presence or absence of $10 \mathrm{mM} \mathrm{CaCl}_{2}$ was determined. Briefly, cells were vortexed during $10 \mathrm{~s}$ and allowed to stand for $10 \mathrm{~min}$. Aliquots of $30 \mu \mathrm{L}$ taken from below the meniscus (at 0 and $10 \mathrm{~min}$ ) were used to determine (after proper dilution) the cell density at $570 \mathrm{~nm}$. Flocculation was expressed as the percentage of sedimented cells after $10 \mathrm{~min}$, relative to the initial value.

\subsection{Cellular Hydrophobicity Assay}

Cells were grown in molasses-based medium as described above, washed twice in cold, distilled water, and suspended in water to an absorbance of 0.8 at $570 \mathrm{~nm}$. Hexane was added to the cellular suspensions at a proportion of $1: 3(\mathrm{v}: \mathrm{v})$ and vigorously mixed. The relative difference in cell density of the aqueous phase was determined by measuring the absorbance at $570 \mathrm{~nm}$ before and after vortexing and considered as the hydrophobicity percentage of the cell surface.

\subsection{Biofilm and Invasive Growth Determination}

Biofilm formation was analyzed as described by Reynolds and Fink [60]. The yeast strains were inoculated onto YPD plus $3 \mathrm{~g} / \mathrm{L}$ agar plates with a sterile toothpick. The plates were maintained resting at room temperature, and the yeast colony was measured and photographed after 5 days. For invasive growth assays, the cells were streaked onto standard YPD plus $2 \%$ agar plates, grown at $28{ }^{\circ} \mathrm{C}$ for 5 days, and then photographed. Tap water was used to gently wash non-invasive cells from the surface of the agar, and then the plate was photographed again [40].

\subsection{Amplified Fragment Length Polymorphism Analysis}

Standard methods for DNA manipulation and analysis were employed [61]. Approximately $50 \mathrm{ng}$ of DNA from the different industrial yeast strains, purified using YeaStar columns (Zymo Research, Irvine, CA, USA), according to the manufacturer's recommendations, and 20 pmol of the primers (Table 1) for the AWA1 (AWA1F and AWA1R), FLO1 (FLO1F and FLO1R), and FLO11 (FLO11F and FLO11R) genes were used in $25 \mu \mathrm{L}$ PCR reaction mixture containing standard PCR High Fidelity buffer, $10 \mathrm{mM}$ dNTPs, $1.5 \mathrm{mM} \mathrm{MgCl}$, and $1 \mathrm{U}$ Phusion High-Fidelity DNA polymerase (Finnzymes, Thermo Fisher Scientific Inc., Sinapse Biotecnologia, São Paulo, SP, Brazil). The following PCR program was used 
to amplify fragments: denaturation $\left(10 \mathrm{~s}\right.$ at $\left.98^{\circ} \mathrm{C}\right)$; primer annealing $\left(30 \mathrm{~s}\right.$ at $\left.60{ }^{\circ} \mathrm{C}\right)$ and primer extension $\left(3 \mathrm{~min}\right.$ at $72^{\circ} \mathrm{C}$ ), for 30 cycles. PCR products were fractionated on $0.85 \%$ agarose gels in $40 \mathrm{mM}$ Tris-acetate buffer ( $\mathrm{pH}$ 8.5) plus $2 \mathrm{mM}$ EDTA and visualized with $0.5 \mu \mathrm{g} / \mathrm{mL}$ ethidium bromide staining. Sizes of the amplified fragments were calculated using $1 \mathrm{~Kb}$ DNA ladder (New England Biolabs, Uniscience, Osasco, SP, Brazil) as marker.

Table 1. Plasmids and primers used in this study.

\begin{tabular}{|c|c|}
\hline & Relevant Features or Sequence \\
\hline \multicolumn{2}{|l|}{ Plasmids: } \\
\hline pUG6 & LoxP-KanMX6-LoxP [62] \\
\hline pUG66 & LoxP-Ble ${ }^{\mathrm{R}}-$ LoxP $[62]$ \\
\hline \multicolumn{2}{|l|}{ Primers: } \\
\hline AWA1F & CCGAAGCACTTGCAAAGGATGG \\
\hline AWA1R & GGGAGTTGGAAGCAGTTGCGC \\
\hline FLO1F & GGCAGTCTTTACACTTCTGGCAC \\
\hline FLO1R & AGTATTGGTAGTCGTTTCAGCAGC \\
\hline FLO11F & GATGTGACTTCCGTTTCTTGGG \\
\hline FLO11R & CCGTAGTGACTGATGGAGTTGGAG \\
\hline $\mathrm{HbFLOsF}$ & CAGAAACAACAAAACAACCA \\
\hline HbFLOsR & TTAAATTAATTGCCAGCAATAAG \\
\hline HbFLO11F & CCGTCGTTACTACTGAGTATTC \\
\hline HbFLO11R & TAGAATACAACTGGAAGAGCG \\
\hline INFLO8F & GTTATAAAGTGAATAGTTCGTATC \\
\hline INFLO8R & CGATCTCAATTTACTGGATAC \\
\hline LIM1FLO8F & CACGGCACGTTACTAATTAG \\
\hline LIM1FLO8R & CAGATTAAGGTTTATGATATTTG \\
\hline LIM2FLO8F & GTGACCATTTTTTACTCCTG \\
\hline LIM2FLO8R & CAAGCTACTTCAATGAGTGTAC \\
\hline M1FLO8F1 & GCCCTGGGAGTGGGATACTGAGGAATTAAACGTTTATGCAGGCCCAGCTGAAGCTTCGTACGC \\
\hline M1FLO8R1 & CCAATCATTCCGGCACATCCACCTTGATCAAATATCATAAACCGCATAGGCCACTAGTGGATC \\
\hline M2FLO8F1 & CGCATTCCGTGGTAGAATGAGTTATAAAGTGAATAGTTCGCCAGCTGAAGCTTCGTACGC \\
\hline M2FLO8R1 & CGTAACTCCATTCTCCTAGCTTTTTATTATGTTTCCTGTCGCATAGGCCACTAGTGGATC \\
\hline SDKANF & CCGCGATTAAATTCCAACAT \\
\hline SDKANR & CGAGCATCAAATGAAACTG \\
\hline SDBLEF & GAGATCTGTTTAGCTTGCCT \\
\hline SDBLER & GTTAGTATCGAATCGACAGCA \\
\hline V1FLO8F & GGCTCTAGTAGTAACAAAAATAG \\
\hline V3FLO8F & CTGAGGGACCTATTGTATGC \\
\hline $\mathrm{VKan}^{\mathrm{R}} \mathrm{R}$ & GGAATCGAATGCAACCGG \\
\hline $\operatorname{VBLE}^{\mathrm{R}} \mathrm{F}$ & ССТTCTATGAAAGGTTGGGC \\
\hline
\end{tabular}

Underlined sequences allow amplification of the transformation modules present in plasmids pUG6 and pUG66 [62].

\subsection{Construction of Flo8 $\Delta$ Knockout Strains}

Yeast transformation was performed by the lithium acetate method [44]. The FLO8 gene was deleted according to the polymerase chain reaction (PCR)-based gene replacement procedure [62]. Briefly, the kanMX cassette from plasmid pUG6 (Table 1) was amplified with primers M1FLOF1 and M1FLO8R1 (Table 1), and the resulting PCR product of 1779-bp was used to transform competent yeast cells [63] from the laboratory strain S288C. After 2-h cultivation on YP-2\% glucose, the transformed cells were plated on the same medium containing G-418 and incubated at $28{ }^{\circ} \mathrm{C}$. G-418-resistant isolates were tested for proper genomic integration of the kanMX cassette at the FLO8 locus by analytical colony PCR using primers (V1FLO8F and INFLO8R; Table 1) that yielded a 2857-bp fragment from a normal FLO8 locus or with primers (V3FLO8F and VKan ${ }^{\mathrm{R}} \mathrm{R}$, Table 1) that amplified a 1394-bp fragment if the kanMX cassette was correctly integrated at this locus and replaced the FLO8 gene, yielding strain S288C-flo8 $1:$ kanMX. Using the same strategy above, the FLO8 gene was deleted from the genome of the laboratory strain CEN.PK2-1C using primers M2FLO8F1 and M2FLO8R1 (Table 1) to amplify the Ble $e^{\mathrm{R}}$ gene from plasmid pUG66 [62]. 
The resulting PCR product of 1344-bp was used to transform competent yeast cells and zeocin-resistant isolates were tested for proper genomic integration of the $B l e^{\mathrm{R}}$ gene at the FLO8 locus by Southern analysis (see below) or analytical colony PCR using primers V1FLO8F and INFLO8R, as described above, or with primers LIM2FLO8R and VBLE ${ }^{R} F$ (Table 1) that amplified a 956-bp fragment if the FLO8 gene was deleted and replaced by $B l e^{\mathrm{R}}$, yielding strain CEN.PK2-1C-flo8 $\Delta:: B l e^{\mathrm{R}}$. To delete both copies of the FLO8 gene present in the industrial diploid strain FT859, we used a long-flanking-homology approach [62] by using primers LIM1FLO8F and LIMFLO8R (Table 1) to amplify a 2118-bp fragment form the DNA of strain S288C-flo8 $4:$ kanMX or primers LIM2FLOF and LIM2FLO8R (Table 1) to amplify a 1646-bp fragment from the DNA of strain CEN.PK2-1C-flo8 $\Delta:$ Ble ${ }^{\mathrm{R}}$. After selection of transformants in G-418 and zeocin plates, the proper genomic integration of the kanMX and Ble $e^{\mathrm{R}}$ genes at the FLO8 locus was confirmed by Southern analysis (see below) or analytical colony PCR, as described above, yielding the industrial-modified strain CFY02B-B (FT859 flo8 ::kanMX/flo8 $:: B l e^{\mathrm{R}}$ ).

\subsection{PFGE, Chromosome Blotting, and Hybridization}

Yeast chromosomes were prepared as previously described [64] from $1 \mathrm{~mL}$ of yeast cells pre-grown in YPD medium and collected at the stationary phase of growth. Cells were washed with $10 \mathrm{mM}$ Tris- $\mathrm{HCl}, \mathrm{pH} 7.5$, containing $50 \mathrm{mM}$ EDTA, and resuspended in the $0.4 \mathrm{~mL}$ of $4 \mathrm{mM}$ Tris-HCl, pH 7.5, containing $95 \mathrm{mM}$ EDTA, $130 \mu \mathrm{g} / \mathrm{mL}$ of Zymolyase 20 T (Sigma-Aldrich Brasil Ltda., São Paulo, SP, Brazil), and 0.7\% of molten $\left(42^{\circ} \mathrm{C}\right)$ lowmelting-point agarose. After solidification in a mold (Amersham Pharmacia Biotech do Brasil Ltda., São Paulo, SP, Brazil), the agarose blocks were immersed in $10 \mathrm{mM}$ Tris- $\mathrm{HCl}$, $\mathrm{pH} 7.5$, containing $0.5 \mathrm{M}$ EDTA, and incubated at $37^{\circ} \mathrm{C}$ for $8 \mathrm{~h}$. Following a subsequent incubation in $10 \mathrm{mM}$ Tris- $\mathrm{HCl}, \mathrm{pH} 9.5$, containing $0.5 \mathrm{M}$ EDTA, $1 \% \mathrm{~N}$-lauroylsarcosine, and $2 \mathrm{mg} / \mathrm{mL}$ proteinase $\mathrm{K}$ at $50{ }^{\circ} \mathrm{C}$ overnight, the blocks were washed in $10 \mathrm{mM}$ Tris$\mathrm{HCl}, \mathrm{pH} 7.5$, containing $50 \mathrm{mM}$ EDTA, and stored at $4{ }^{\circ} \mathrm{C}$ in the same buffer. Each low-melting-point agarose block was transferred to a $1 \%$ agarose gel in $50 \mathrm{mM}$ Tris- $\mathrm{HCl}$, $\mathrm{pH} 8.3$, containing $50 \mathrm{mM}$ boric acid and $1 \mathrm{mM}$ EDTA. Pulsed field gel electrophoresis (PFGE) was performed at $8{ }^{\circ} \mathrm{C}$ using a Gene Navigator pulsed field system (Amersham Pharmacia Biotech Pharmacia Biotech do Brasil Ltda., São Paulo, SP, Brazil) for a total of $27 \mathrm{~h}$ at $200 \mathrm{~V}$. The pulse time was stepped from $70 \mathrm{~s}$ after $15 \mathrm{~h}$ to $120 \mathrm{~s}$ for $12 \mathrm{~h}$. Following electrophoresis, the gel was stained with ethidium bromide and photographed (Gel Doc ${ }^{\mathrm{TM}}$ XR, Bio-Rad Laboratories, Hercules, CA, USA).

The chromosomes separated by PFGE were transferred to a nylon filter (Hybond$\mathrm{N}^{+}$, GE Healthcare, Barueri, SP, Brazil) by capillary blotting [61], and labeling of DNA probes (see below), including the pre-hybridization, hybridization, stringency washes, and chemiluminescent signal generation and detection was performed by using a AlkPhos kit (GE Healthcare, Barueri, SP, Brazil) as recommended by the manufacturer. After hybridization, an autoradiography film (Hiperfilm ${ }^{\mathrm{TM}}$ ECL, Kodak, GE Healthcare, Barueri, $\mathrm{SP}$, Brazil) was exposed to the membrane for 1 to $2 \mathrm{~h}$ before it was developed. Images were obtained with Image Lab Software (Gel Doc ${ }^{\mathrm{TM}}$ XR, Bio-Rad Laboratories, Hercules, CA, USA) and annotated with Microsoft PowerPoint. Probes were generated by PCR using DNA from strain S288C or plasmids pUG6 and pUG66 as templates and primers (Table 1) INFLO8F and INFLO8F for the FLO8 gene, HbFLOsF and HbFLOsR for FLO1, HbFLO11F and HbFLO11F for the FLO11 gene, SDKanF and SDKanR for kanMX, and SDBleF and SDBleR for the $B l e^{\mathrm{R}}$ gene, respectively.

\section{Results}

\subsection{Foam Production by Industrial Yeast Strains}

We analyzed 15 industrial yeast strains isolated during fermentative fuel-ethanol production processes in Brazil. This group included two strains (PE-2 and CAT-1) with good industrial fermentation characteristics, such as non-flocculent cells with high fermentative capacity, dominance of the industrial fermenters, and production of very small amounts 
of foam during industrial fuel-ethanol production, and, consequently, these two strains are used by more than half of the industrial fuel-ethanol companies in Brazil $[4,19,23]$. The other 13 industrial strains (BAT-1 and FT278 through FT859) showed some undesired industrial characteristics, such as premature flocculation and/or sedimentation or excessive foam production during industrial fermentation processes, generally leading to problematic/stuck fermentations with residual sugars not completely fermented in the vats.

Figure 1 shows the kinetics of foam production during fermentation of molasses-based medium by three representative strains (CAT-1, BAT-1, and FT281). Strain CAT-1 produced less than $10 \%(v / v)$ of foam during fermentation, while strains BAT-1 and FT281 produced significant amounts of foam (more than $60 \%$ for strain BAT-1 and up to $90 \%$ for strain FT281), with significant differences in the kinetics of foam production. Strain FT281 started to produce foam early during fermentation, and the maximum production peaked after $2 \mathrm{~h}$, but, soon after that, the foam started to decrease and disappeared after 4 to $5 \mathrm{~h}$ of fermentation (Figure 1). Strain BAT-1 started to produce foam earlier during fermentation, but, once the foam accumulated, it persisted all along the $8 \mathrm{~h}$ of fermentation (Figure 1). We observed the presence of high amounts of yeast cells attached to this highly stable, thick, dense, and persistent foam (data not shown). Figure 2 shows the maximum amount of foam produced by all the 15 industrial yeast strains analyzed. Some of them (strains CAT-1, PE-2, FT279, FT540, and FT718) were considered as poor foam producers (less than $20 \%$ of the total volume), while the other 10 strains produced $35 \%$ or more of foam during fermentation, the majority with a stable and persistent foam all along the fermentation (the exceptions were strains FT281, FT705, and FT714, see Figures 1 and 2).

A

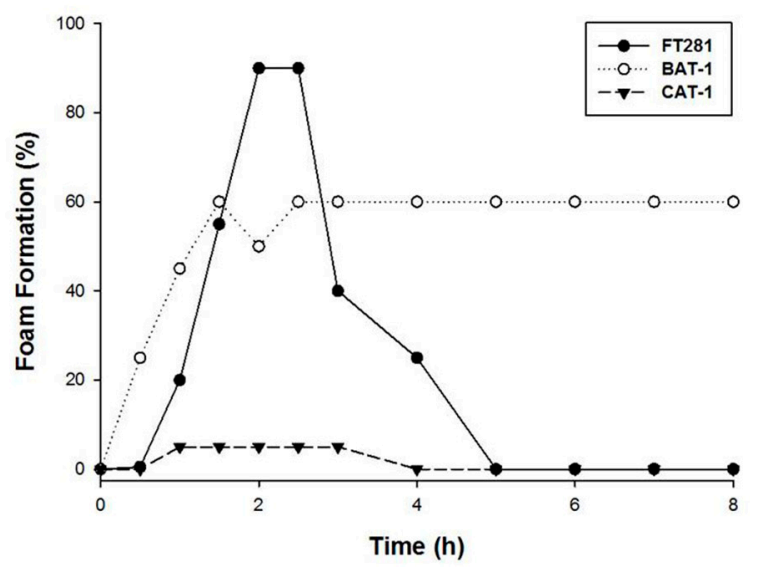

B

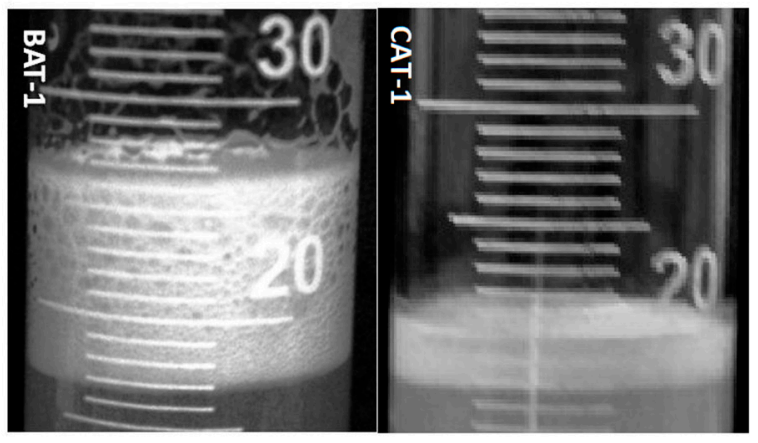

Figure 1. Foam production during fermentation. (A) Kinetics of foam formation (volume of foam as a percentage of the media volume) during fermentation of molasses-based medium containing $20 \mathrm{~g} / \mathrm{L}$ of total sugars by three representative industrial strains. (B) Foam produced after $3 \mathrm{~h}$ of fermentation by strain BAT-1 (left panel) or strain CAT-1 (right panel).

\subsection{Flocculation and Cellular Hydrophobicity of Industrial Yeast Strains}

Yeast strains were grown in molasses-based medium and flocculation assays were performed in the presence or absence of $20 \mathrm{mM} \mathrm{Ca}^{2+}$, and at least three different patterns of yeast flocculation were observed (Figure 3). Six industrial strains showed a high cellular sedimentation ( $>60 \%$ of flocculation), which was mostly calcium independent and only one of them (strain FT718) was not a strong foam producer (see Figure 2). A second group included four industrial yeast strains that presented calcium-dependent flocculation, as the sedimentation rate in absence of calcium was lower than $30 \%$, but increasing to approximately 50\% after $\mathrm{Ca}^{2+}$ addition (Figure 3). Finally, the remaining five strains (including strains CAT-1 and PE-2) were either non-flocculent or showed an insignificant flocculation rate (less than $30 \%$ ) in the presence or absence of calcium. 


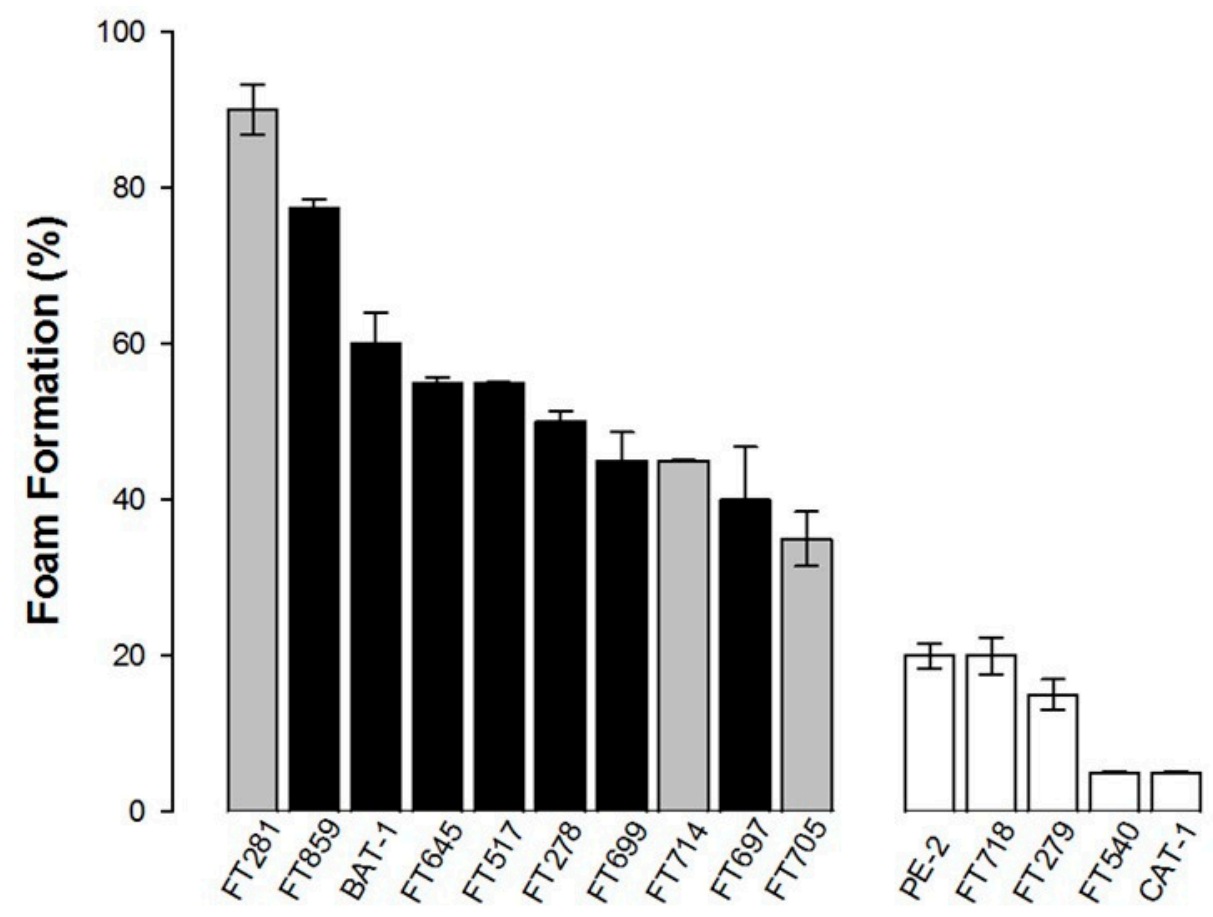

Figure 2. Foam produced during fermentation (volume of foam as a percentage of the media volume) by the analyzed industrial fuel-ethanol yeast strains. White columns are strains that produce small amounts of foam, gray columns are strains that produce a non-persistent foam, and persistent foaming strains are in black columns.

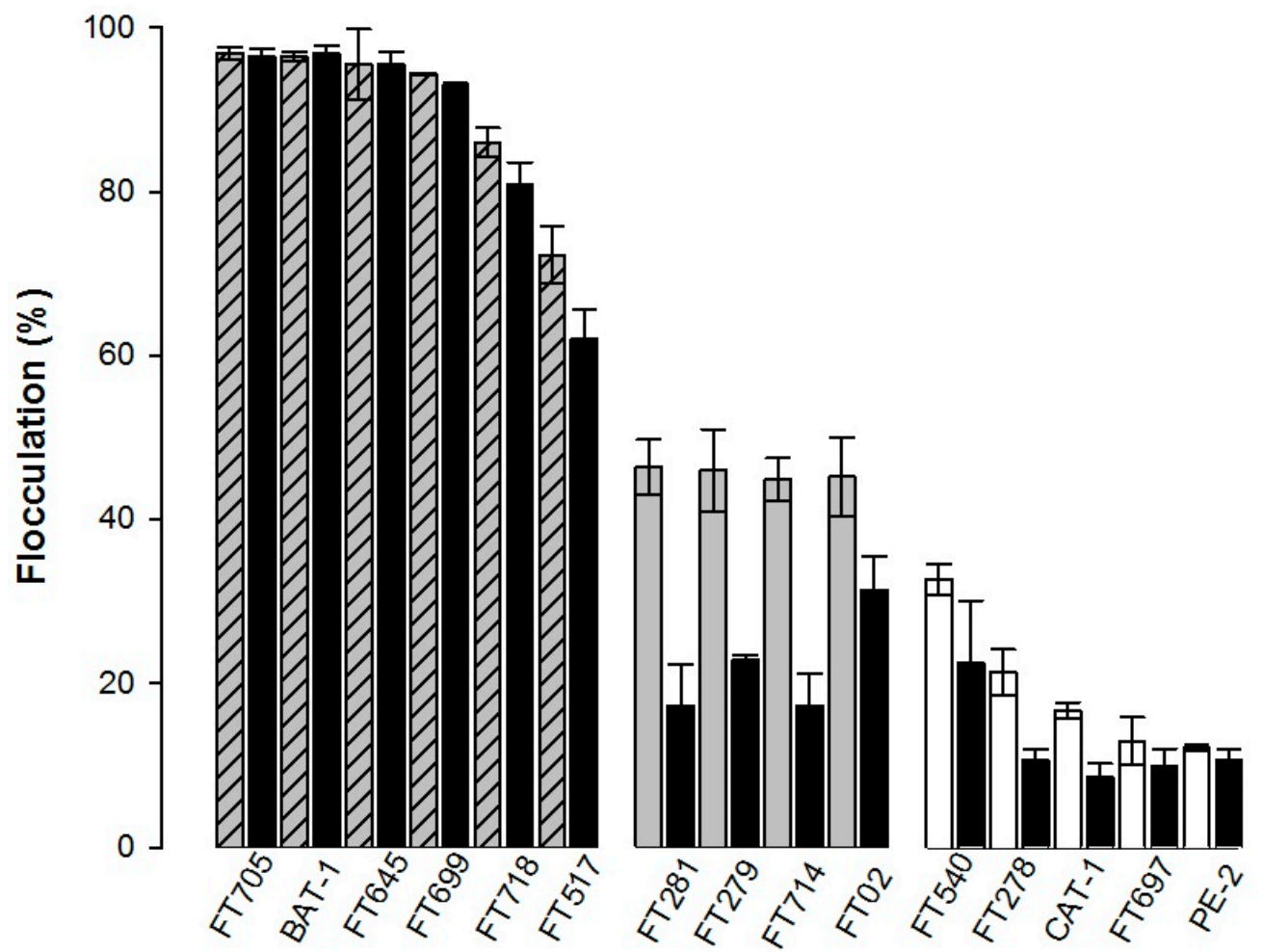

Figure 3. Cellular flocculation by the analyzed industrial fuel-ethanol yeast strains. Flocculation was determined as the percentage of sedimented cells after $10 \mathrm{~min}$ in rest, in the absence (black bars) or presence (white, grey, and striped grey bars) of $20 \mathrm{mM} \mathrm{Ca}^{2+}$. 
In order to quantify the cell wall hydrophobicity of the industrial strains, we analyzed the cellular partitioning into an organic solvent such as hexane. Our results showed a significant variability in cellular hydrophobicity among the industrial yeast strains (Figure 4), but, again, strains CAT-1 and PE-2 were the ones with the lowest cellular hydrophobicity. Among those strains with high cellular hydrophobicity $(60 \%$ or more of cells partition into the organic solvent), it is worth to note that all of them had strong flocculation phenotypes (see Figure 3) and only one (strain FT718) was a poor foam producer (see Figure 2).

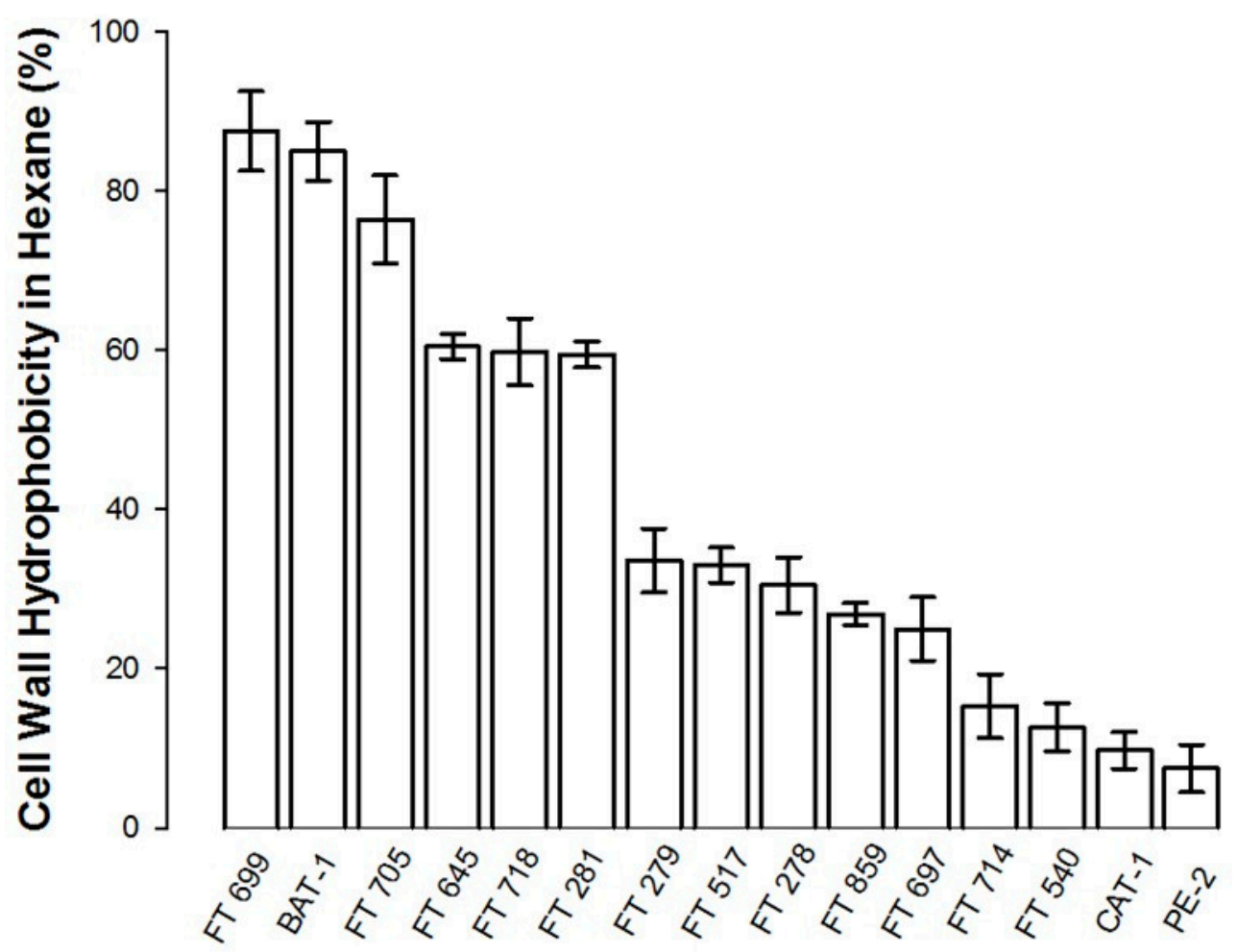

Figure 4. Cellular hydrophobicity of the analyzed industrial fuel-ethanol yeast strains. The hydrophobicity of the cells suspended in water was quantified by means of a biphasic partitioning assay using hexane as hydrophobic solvent.

\subsection{Invasive Growth and Biofilm Formation by Industrial Yeast Strains}

Figure 5 shows some patterns of invasive growth and biofilm formation by the industrial strains and in Table 2 are scored the size of mats and the degree of invasiveness into YPD agar plates for all strains. The industrial strains CAT-1 and PE-2 showed significant attachment to the agar surface and, while the other strains were either similar or even less invasive than these two strains, only one (strain FT278) attached firmly into the plate surface. Despite the highly variable size of the biofilms formed by the strains (diameters ranging from 1.2 to $4.5 \mathrm{~cm}$ after 5 days), the mats they produced were smooth and did not form highly structured "fluffy" biofilms, as described earlier for several other laboratory and wild yeast strains $[60,65,66]$. Nevertheless, biofilm formation seems to be directly correlated to flocculation, since all strong flocculent industrial strains were able to form biofilms larger than $3.5 \mathrm{~cm}$ and all non-flocculant strains formed biofilms smaller than $1.5 \mathrm{~cm}$. 
A $\quad$ S288C
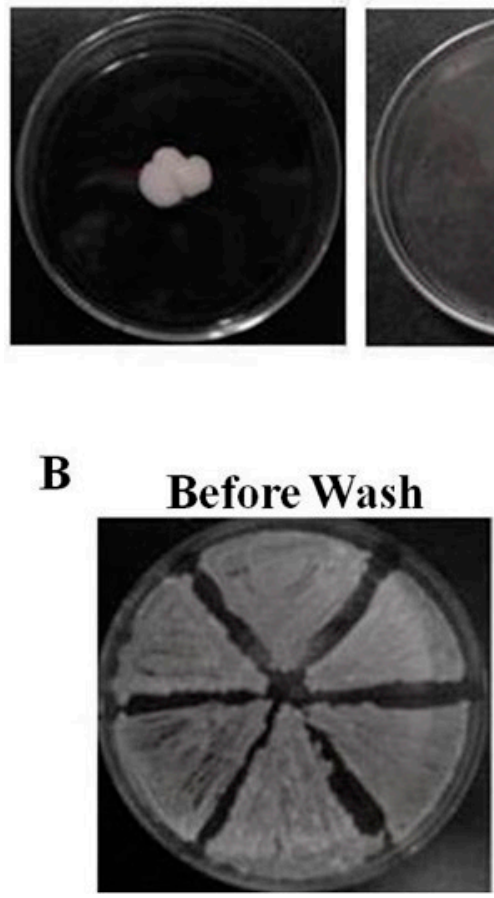

CAT-1

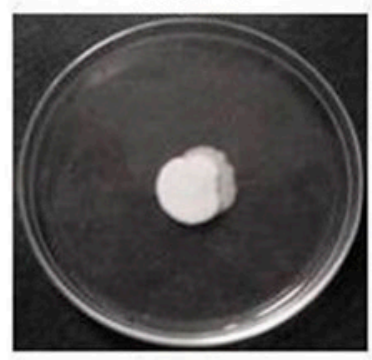

FT718

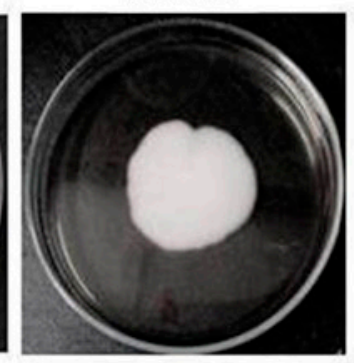

BAT-1

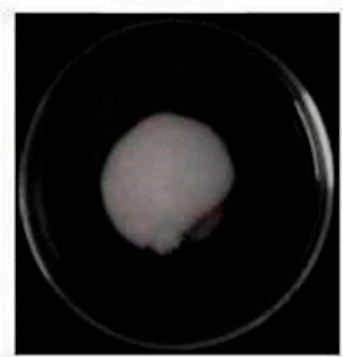

Figure 5. Biofilm formation and invasive growth by the analyzed industrial fuel-ethanol yeast strains. (A) Examples of biofilms (mats) produced by the indicated strains after 5 days in low agar (0.3\%) plates. (B) Invasive growth, scored as adhesion to agar surfaces, was determined by patching the yeast cells on YPD plates and incubation for 5 days. The plate was documented before and after gentle washing with water. Strains BAT-1 and FT645 were considered non-adhesive ("-" in Table 2), while the other strains showed different strengths of invasive growth (scored "+" to " +++ " in Table 2).

Table 2. Biofilm, invasive growth, and FLO gene polymorphisms of the industrial strains analyzed in this study.

\begin{tabular}{|c|c|c|c|c|}
\hline \multirow{2}{*}{$\begin{array}{c}\text { Industrial Yeast } \\
\text { Strains: }\end{array}$} & \multirow{2}{*}{ Biofilm (cm) ${ }^{1}$} & \multirow{2}{*}{$\begin{array}{l}\text { Invasive } \\
\text { Growth }{ }^{2}\end{array}$} & \multicolumn{2}{|c|}{ PCR Product ${ }^{3}(\mathrm{~Kb})$ for Gene } \\
\hline & & & FLO1 & FLO11 \\
\hline CAT-1 & 2.0 & ++ & 1.3 & 2.1 \\
\hline PE-2 & 2.0 & ++ & 0.8 & 0.8 \\
\hline BAT-1 & 4.5 & - & 3.2 & 2.7 \\
\hline FT278 & 1.5 & +++ & 2.9 & 2.4 \\
\hline FT279 & 3.0 & - & 2.9 & 2.5 \\
\hline FT281 & 1.5 & - & 5.0 & 2.8 \\
\hline FT517 & 3.5 & ++ & - & 2.6 \\
\hline FT540 & 1.2 & + & 3.2 & 0.5 \\
\hline FT645 & 4.0 & - & 3.4 & 2.9 \\
\hline FT697 & 1.5 & ++ & 4.9 & - \\
\hline FT699 & 4.0 & - & - & 2.7 \\
\hline FT705 & 4.0 & + & - & 2.7 \\
\hline FT714 & 3.0 & + & - & 2.6 \\
\hline FT718 & 4.5 & + & - & 2.0 \\
\hline FT859 & 1.6 & ++ & 3.0 & 2.6 \\
\hline
\end{tabular}

${ }^{1}$ Diameter of the mat/biofilm. ${ }^{2 ~ "}-$ " indicates absence of a characteristic (or gene), and " + " to " +++ " the presence and strength of the characteristic (see Figure 5). ${ }^{3}$ The expected amplified fragment, based on the genome of strain $\mathrm{S} 288 \mathrm{C}$, is $4.3 \mathrm{~Kb}$ for $F L O 1$ and $3.1 \mathrm{~Kb}$ for FLO11.

\subsection{Presence and Flocculin Gene Size Polymorphisms}

We designed primers to amplify the highly variable and repetitive serine/threoninerich middle domain present in several GPI-linked cell-wall proteins (Table 1). Considering the highly foaming phenotypes present by some members of this group of industrial 
yeast strains, we initially tried to amplify and verify fragment length polymorphisms in the already described AWA1 foaming gene [52-54]. However, we could not amplify any fragment for this gene from the DNA of any of the industrial yeast strains analyzed. Thus, we focused or analysis on two other important flocculin genes, FLO1 and FLO11 (Table 2). The FLO1 gene was found in $66 \%$ of the industrial yeast strains analyzed and presented significant length polymorphism in the serine/threonine-rich middle domain among the strains (sizes varied from 0.8 to $5.0 \mathrm{~Kb}$ ), and only two strains (FT281 and FT697) showed PCR fragments longer that the expected $4.3 \mathrm{~Kb}$ fragment that is predicted from the known genome of strain S288C. Regarding FLO11, only strain FT697 showed no amplified fragment, and the other analyzed industrial strains showed DNA fragments of varying length polymorphisms (from 0.5 to $2.9 \mathrm{~Kb}$ ), all of them with lower sizes than the expected size of $3.1 \mathrm{~Kb}$ obtained for this gene from the genome of strain S288C.

Nevertheless, we analyzed possible significant correlations (using STATISTIX 8.0 ${ }^{\circledR}$ Analytical Software, Tallahassee, FL, USA) between the size polymorphisms of these two genes and the phenotypic variability shown by the corresponding industrial strains (Figures 1-5, Table 2). There was a significant correlation of FLO11 length polymorphisms and foam production, cellular hydrophobicity, and flocculation $\left(r^{2} \geq 0.50\right.$ and $p \leq 0.05$, Spearman nonparametric test). For FLO1 length polymorphisms, the more significant correlation observed was with cellular hydrophobicity $\left(r^{2} \geq 0.62\right.$ and $\left.p \leq 0.05\right)$ and, to a lesser extent, with foam production $\left(r^{2} \geq 0.42\right.$ and $\left.p \leq 0.05\right)$. Consequently, there was also a significant correlation between foam production during fermentation and the cellular hydrophobicity $\left(r^{2} \geq 0.50\right.$ and $\left.p \leq 0.05\right)$, while this last parameter was significantly correlated with flocculation (in the presence or absence of calcium, $r^{2} \geq 0.70$ and $p \leq 0.05$ ) and biofilm formation $\left(r^{2} \geq 0.42\right.$ and $p \leq 0.05$, Pearson parametric test).

\subsection{Deletion of FLO8 Reduces Foam Production by an Industrial Yeast Strain}

Considering the correlation between FLO11 (and also FLO1) gene length polymorphisms and foam production during fermentation by the industrial yeast strains, we decided to see the phenotypic consequences of deleting the FLO8 gene, encoding one of the key transcriptional activators of the FLO1 and FLO11 genes [40,67], in one of the industrial yeast strains (FT859), a strain that produces large amounts of persistent foam (Figure 2), while in the other characteristics we analyzed it had intermediate (e.g., flocculation and invasive growth) to low (e.g., cellular hydrophobicity and biofilm formation) values (Figures 3-5, Table 2). We initially deleted the FLO8 gene from two laboratory yeast strains (using different markers, see Materials and Methods) and afterward we used the long-flanking-homology approach [62] to delete this gene from the diploid genome of the industrial strain FT859. Figure 6 shows a PFGE and blotting analysis of the strains, confirming that the $\mathrm{FLO} 8$ gene was specifically removed from the genome of the industrialmodified strain CFY02B-B (FT859 flo8 $:: k a n M X / f l o 8 \Delta:: B l e^{\mathrm{R}}$ ) and also showing the presence of both the FLO1 (chromosome I) and FLO11 (chromosome IX) genes in its genome.

Strain CFY02B-B (FT859 flos $\Delta /$ flos $\Delta$ ) had no difference in cellular hydrophobicity when compared to strain FT859, but showed a pronounced drop in the flocculation capacity ( 15 and $20 \%$ of sedimented cells in the absence and presence of $\mathrm{Ca}^{2+}$, compared to 32 and $45 \%$ obtained with strain FT859, see Figure 3), biofilm formation (mats of $0.9 \mathrm{~cm}$ of diameter, compared to $1.6 \mathrm{~cm}$ for strain FT859, see Table 2), invasive growth (strain CFY02B-B lost its capacity to adhere to the agar surface, while strain FT859 does, see Table 2) and, as shown in Figure 7, also lost its capacity to produce high amounts of foam during fermentation, indicating that induction of $F L O$ genes by FLO8 is required for foam production by this contaminant industrial yeast strain. 


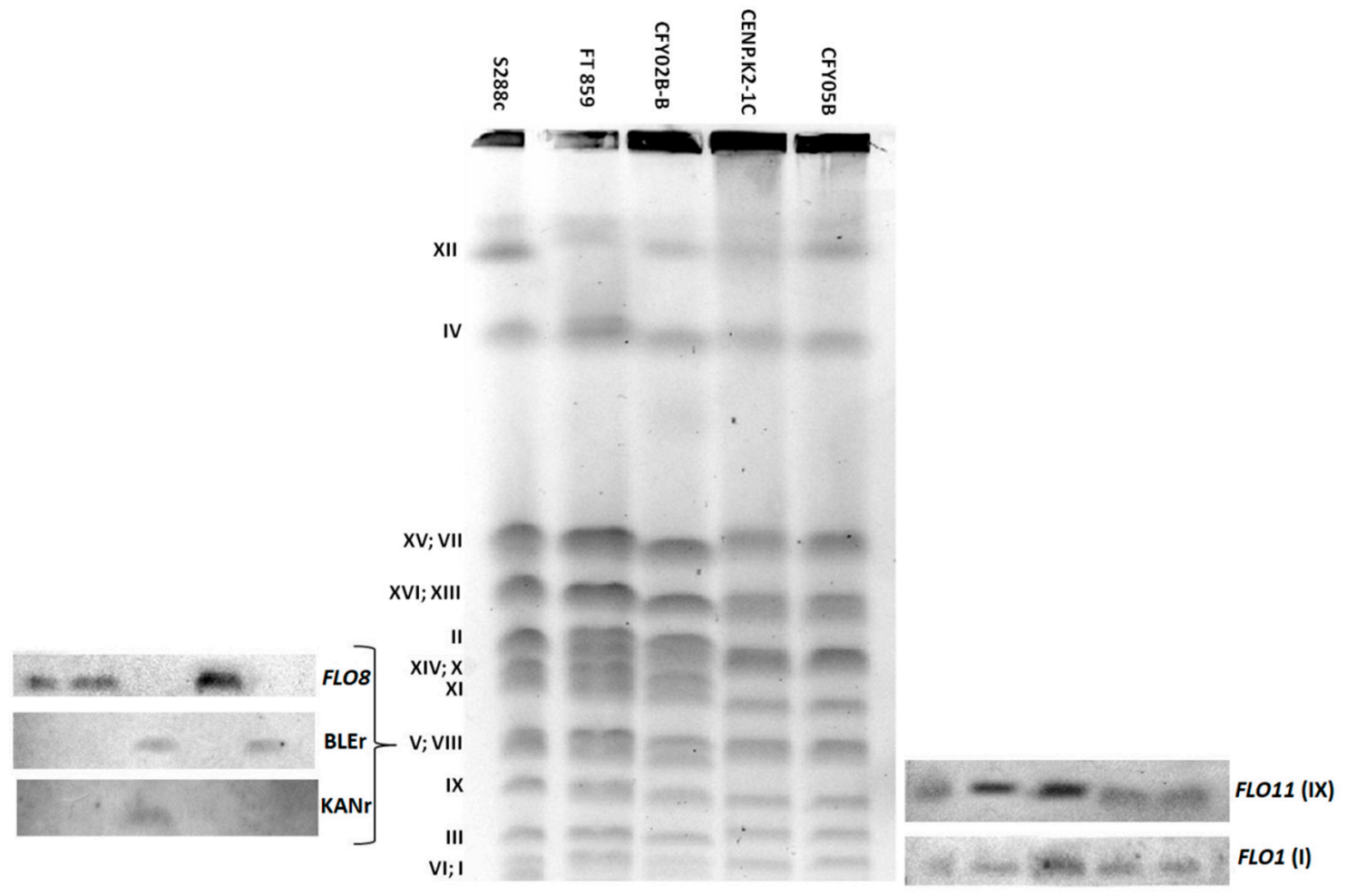

Figure 6. Confirmation of FLO8 deletion in the industrial fuel-ethanol strain FT859. The middle panel shows the separation of chromosomes of the yeast strains by PFGE and staining with ethidium bromide, while the detection of FLO1 and FLO11 genes (right panels) or the presence/absence of the FLO8, Ble $e^{\mathrm{R}}$ (BLEr), and kanMX (KANr) genes (left panels) in their genomes was determined after the chromosomes were blotted onto a nylon membrane and hybridized with specific probes. The Roman numerals are the chromosome numbers based on S288C chromosomes. In line 1 is strain S288C, in line 2 strain FT859, in line 3 strain CFY02B-B (strain FT859, but flo8 $\Delta:: B l e^{\mathrm{R}} / f l o 8 \Delta:: k a n M X$ ), in line 4 strain is CEN.PK2-1C, and in line 5 is strain CEN.PK2-1C -flos $\Delta:: B l e^{\mathrm{R}}$.

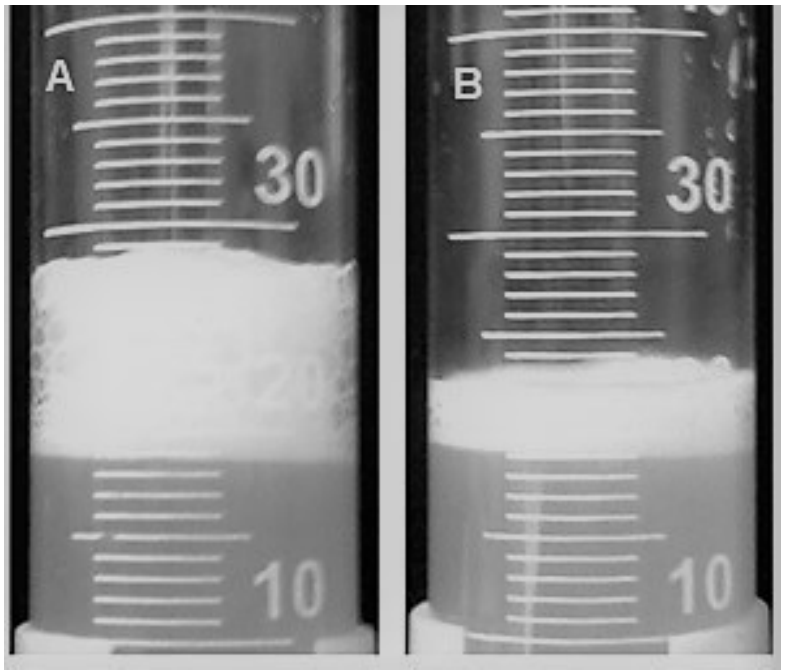

Figure 7. Deletion of FLO8 prevents foam production by the industrial fuel-ethanol strain FT859. The foam produced by strain FT859 (A) or its isogenic flo8 $:: B l e^{\mathrm{R}} /$ flo8 $\Delta:: k a n M X$ strain CFY02B-B (B) was documented after $3 \mathrm{~h}$ of fermentation.

\section{Discussion}

The analysis of hundreds of indigenous $S$. cerevisiae strains isolated from industrial sugarcane fuel-ethanol producing plants in Brazil revealed that more than $67 \%$ of the strains 
produced excessive amounts of foam. Only $20 \%$ of the strains did not present undesirable features, including foam, premature flocculation or inability to metabolize all sugar from the medium [19]. Yeasts growing in nature usually form organized multicellular structures (colonies, biofilms) with specific properties that do not normally arise under laboratory conditions. The cooperation of yeast cells and their growth within a community is beneficial in harmful or stressful conditions and might contribute to successful colonization of new environments. Consequently, these morphological transitions from a single-cell budding yeast that forms into organized structures are regulated by several sensing/signaling pathways that allow the formation of pseudohyphae and biofilms and promote their adhesion to other cells or surfaces $[49,68,69]$.

In the case of the Brazilian sugarcane fuel-ethanol production plants there is not only several stressful conditions during the industrial process, but sucrose, the main sugar found in sugarcane juice that the cells will have to ferment [1], is one of the strongest inducers of pseudophyphal growth and filamentation in yeasts [70,71]. For example, after serial transfers of yeast cells in low sucrose-containing medium, of 12 evolved clones, 11 formed multicellular clumps through incomplete cell separation [72], due mainly to nonsense or frameshift mutations in the ACE2 gene, encoding for the transcription factor required for septum destruction after cytokinesis [73-75]. Indeed, even a good industrial fuelethanol strain like PE-2 can eventually show recurrent appearance of mutants displaying a mother-daughter cell separation defect resulting in rough colonies in agar media and fast sedimentation in liquid culture [76]. This diploid strain was shown to be heterozygous for a frameshift mutation in the $A C E 2$ gene (ACE2/ace2-A7) and, thus, loss-of-heterozygosity events at the region of chromosome XII where ACE2 is located can produce ace2-A7/ace2-A7 cells with the undesirable phenotype of cellular aggregation [76]. Nevertheless, other reports indicate that mutations that increase the expression of the flocculin genes FLO1 and FLO11 are the favored routes to flocculation in yeasts [75,77].

Our results showed a great diversity of morphological and cell-surface-associated phenotypes in the group of 15 wild and indigenous yeast strains isolated from industrial fuel-ethanol production processes in Brazil that we analyzed. We not only found $\mathrm{Ca}^{2+}$ dependent and -independent flocculation phenotypes, but also some strains showing significant invasive growth, a characteristic of haploid yeast cells not described in diploid strains (as are the industrial strains analyzed). While most laboratory strains do not show these dimorphic transitions or flocculate due to a mutation that inactivates the transcriptional activator encoded by the $F L O 8$ gene $[39,40,78]$, the known genome of two Brazilian industrial strains included in our study (strains CAT-1 and PE-2, see [57,58]) revealed that these strains have a functional FLO8 gene, but are non-flocculent and do not produce foam due to absence or significant polymorphisms in the coding regions of their flocculin FLO genes (including FLO1 and FLO11, see Table 2).

Although we did not perform a comprehensive analysis of the FLO genes present in the industrial fuel-ethanol yeast strains, an important correlation was found between FLO11 length polymorphisms in the genome of the strains and foam production, cellular hydrophobicity, and flocculation. FLO11 has been implicated in the interaction of yeasts with air-liquid interfaces $[44,51,79,80]$, which is in agreement with our results that indicate the presence of yeast cells in the highly persistent foam produced by some of the industrial strains (Figures 1 and 2). Although none of the industrial strains analyzed had a FLO11 gene with the predicted size (based on strain S288C, see Table 2), but instead had shorter version of the gene, it is also worth noting that all these strains produced biofilms (of variable sizes) that were smooth, resembling the mats and colonies produced by flo11 $\Delta$ strains $[60,65]$. Not only increased central tandem repeat domains of the $F L O 11$ coding region were shown to be responsible for the formation of buoyant biofilms at the medium surface, but also alterations in the FLO11 promoter region have been implicated in floating phenotypes of wild flor yeast strains $[44,79,80]$. Indeed, the FLO11 promoter is one of the biggest promoters described in yeasts $(\sim 2.8 \mathrm{~Kb})$, with several cis-regulatory elements (four activating and at least nine repressing sequences) and numerous trans-acting factors implicated in its 
regulation, including posttranscriptional and epigenetic control by chromatin remodeling complexes, as well as prions [69,81-84]. While expression of the FLO11 gene has been shown to be induced under limiting nutritional conditions [85,86], it will be interesting to analyze the expression of this gene during the fermenting conditions that produce high foaming phenotypes in the different genetic backgrounds of the industrial fuel-ethanol yeast strains analyzed. It is worth noting that yeast strains with flocculating phenotypes can easily appear from non-flocculating yeasts cultures $[72,74,77,79,87]$. Nevertheless, our results indicate that deleting the primary activator of $F L O$ genes (the FLO8 gene) from the genome of an industrial strain avoids problematic foam formation, flocculation, invasive growth, and biofilm production. From an industrial perspective, it is difficult to imagine deleting all functional flocculin genes in a selected strain to warranty singlecell budding yeasts and, thus, the strategy described in this work (FLO8 deletion) opens new perspectives for yeast strain engineering and optimization in the growing sugarcane fuel-ethanol industry.

\section{Conclusions}

Our molecular analysis of FLO1 and FLO11 gene polymorphisms present in contaminant strains of $S$. cerevisae from fuel ethanol distilleries showing strong foam production during fermentation revealed significant correlations with cellular hydrophobicity, flocculation, and highly foaming phenotypes in these yeast strains. Our results also show that deleting the primary activator of $F L O$ genes (the $F L O 8$ gene) from the genome of a contaminant and highly foaming industrial strain avoids problematic foam formation, flocculation, invasive growth, and biofilm production by the engineered strain.

Author Contributions: Conceptualization, H.V.d.A. and B.U.S.; investigation, methodology, and formal analysis, C.M.d.F., D.H.H., D.T. and M.d.L.B.M.; resources, H.V.d.A., M.L.L. and B.U.S.; writing-review and editing, M.L.L. and B.U.S.; project administration and funding acquisition, B.U.S. All authors have read and agreed to the published version of the manuscript.

Funding: This work was supported in part by grants and fellowships from the Brazilian agencies CNPq (process nos. 482905/2007-7, 143269/2009-7, 551392/2010-0, and 308389/2019-0).

Institutional Review Board Statement: Not applicable.

Informed Consent Statement: Not applicable.

Data Availability Statement: The data presented in this study are available in the article.

Conflicts of Interest: The authors declare no conflict of interest. The funders had no role in the design of the study; in the collection, analyses, or interpretation of data; in the writing of the manuscript; or in the decision to publish the results.

\section{References}

1. Marques, W.L.; Raghavendran, V.; Stambuk, B.U.; Gombert, A.K. Sucrose and Saccharomyces cerevisiae: A relationship most sweet. FEMS Yeast Res. 2016, 16, fov107. [CrossRef] [PubMed]

2. Jaiswal, D.; de Souza, A.P.; Larsen, S.; LeBauer, D.S.; Miguez, F.E.; Sparovek, G.; Bollero, G.; Buckeridge, M.S.; Long, S.P. Brazilian sugarcane ethanol as an expandable green alternative to crude oil use. Nat. Clim. Change 2017, 7, 788-792. [CrossRef]

3. Amorim, H.V.; Lopes, M.L.; Oliveira, J.V.C.; Buckeridge, M.S.; Goldman, G.H. Scientific challenges of bioethanol production in Brazil. Appl. Microbiol. Biotechnol. 2011,91, 1267-1275. [CrossRef]

4. Della-Bianca, B.E.; Basso, T.O.; Stambuk, B.U.; Basso, L.C.; Gombert, A.K. What do we know about the yeast strains from the Brazilian fuel ethanol industry? Appl. Microbiol. Biotechnol. 2013, 97, 979-991. [CrossRef]

5. Lopes, M.L.; Paulillo, S.C.; Godoy, A.; Cherubin, R.A.; Lorenzi, M.S.; Giometti, F.H.; Bernardino, C.D.; Amorim Neto, H.B.; Amorim, H.V. Ethanol production in Brazil: A bridge between science and industry. Braz. J. Microbiol. 2016, 47, 64-76. [CrossRef]

6. Doerfler, J.; Amorim, H.V. Applied bioethanol technology in Brazil. Sugar Ind. 2007, 132, $694-697$.

7. Godoy, A.; Amorim, H.V.; Lopes, M.L.; Oliveira, A.J. Continuous and batch fermentation processes: Advantages and disadvantages of these processes in the Brazilian ethanol production. Int. Sugar J. 2008, 110, 175-181.

8. Raghavendran, V.; Basso, T.P.; da Silva, J.B.; Basso, L.C.; Gombert, A.K. A simple scaled down system to mimic the industrial production of first generation fuel ethanol in Brazil. Antonie van Leeuwenhoek 2017, 110, 971-983. [CrossRef] 
9. Beckner, M.; Ivey, M.L.; Phister, T.G. Microbial contamination of fuel ethanol fermentations. Lett. Appl. Microbiol. 2011, 53, 387-394. [CrossRef] [PubMed]

10. Costa, O.Y.A.; Souto, B.M.; Tupinambá, D.D.; Bergmann, J.C.; Kyaw, C.M.; Kruger, R.H.; Barreto, C.C.; Quirino, B.F. Microbial diversity in sugarcane ethanol production in a Brazilian distillery using a culture-independent method. J. Ind. Microbiol. Biotechnol. 2015, 42, 73-84. [CrossRef]

11. Lucena, B.T.; dos Santos, B.M.; Moreira, J.L.; Moreira, A.P.; Nunes, A.C.; Azevedo, V.; Miyoshi, A.; Thompson, F.L.; de Morais, M.A., Jr. Diversity of lactic acid bacteria of the bioethanol process. BMC Microbiol. 2010, 10, 298. [CrossRef]

12. Senne de Oliveira Lino, F.; Bajic, D.; Vila, J.C.C.; Sánchez, A.; Sommer, M.O.A. Complex yeast-bacteria interactions affect the yield of industrial ethanol fermentation. Nat. Commun. 2021, 12, 1498. [CrossRef] [PubMed]

13. de Souza-Liberal, A.T.; Basílio, A.; do Monte Resende, A.; Brasileiro, B.; da Silva-Filho, E.A.; de Morais, J.O.; Simões, D.A.; de Morais, M.A., Jr. Identification of Dekkera bruxellensis as a major contaminant yeast in continuous fuel ethanol fermentation. J. Appl. Microbiol. 2007, 102, 538-547. [CrossRef]

14. Basílio, A.C.M.; Araújo, P.R.L.; Morais, J.O.F.; Silva-Filho, E.A.; de Morais, M.A., Jr.; Simões, D.A. Detection and identification of wild yeast contaminants of the industrial fuel ethanol fermentation process. Curr. Microbiol. 2008, 56, 322-326. [CrossRef]

15. De Souza, R.B.; dos Santos, B.M.; de Fátima Rodrigues de Souza, R.; da Silva, P.K.; Lucena, B.T.; de Morais, M.A., Jr. The consequences of Lactobacillus vini and Dekkera bruxellensis as contaminants of the sugarcane-based ethanol fermentation. J. Ind. Microbiol. Biotechnol. 2012, 39, 1645-1650. [CrossRef]

16. Brexo, R.P.; Sant'Ana, A.S. Impact and significance of microbial contamination during fermentation for bioethanol production. Renew. Sustain. Energy Rev. 2017, 73, 423-434. [CrossRef]

17. Stambuk, B.U. Yeasts: The Leading Figures on Bioethanol Production. In Ethanol as a Green Alternative Fuel: Insight and Perspectives, 1st ed.; Treichel, H., Alves, S.L., Jr., Fongaro, G., Müller, C., Eds.; Nova Science Publishers Inc.: Hauppauge, NY, USA, 2019; pp. 57-91.

18. da Silva-Filho, E.; Santos, S.K.; Resende, A.M.; Morais, J.O.; de Morais, M.A., Jr.; Simões, D.A. Yeast population dynamics of industrial fuel-ethanol fermentation process assessed by PCR-fingerprinting. Antonie van Leeuwenhoeck 2005, 88, 13-23. [CrossRef] [PubMed]

19. Basso, L.C.; de Amorim, H.V.; de Oliveira, A.J.; Lopes, M.L. Yeast selection for fuel ethanol production in Brazil. FEMS Yeast Res. 2008, 8, 1155-1163. [CrossRef] [PubMed]

20. Tosin, C.; Andrietta, S.R.; Andrietta, M.G.S. Population dynamics of yeasts inhabiting bioethanol production with cell recycling. J. Inst. Brew. 2015, 121, 343-348. [CrossRef]

21. Reis, V.R.; Antonangelo, A.T.B.F.; Bassi, A.P.G.; Colombi, D.; Ceccato-Antonini, S.R. Bioethanol strains of Saccharomyces cerevisiae characterised by microsatellite and stress resistance. Braz. J. Microbiol. 2017, 48, 268-274. [CrossRef] [PubMed]

22. da Silva-Filho, E.; Melo, H.F.; Antunes, D.F.; dos Santos, S.K.; Resende, M.A.; Simões, D.A.; de Morais, M.A., Jr. Isolation by genetic and physiological characteristics of a fuel-ethanol fermentative Saccharomyces cerevisiae strain with potential for genetic manipulation. J. Ind. Microbiol. Biotechnol. 2005, 32, 481-486. [CrossRef]

23. Stambuk, B.U.; Dunn, B.; Alves, S.L., Jr.; Duval, E.H.; Sherlock, G. Industrial fuel ethanol yeasts contain adaptive copy number changes in genes involved in vitamin B1 and B6 biosynthesis. Genome Res. 2009, 19, 2271-2278. [CrossRef]

24. Ceccato-Antonini, S.R. Biotechnological implications of filamentation in Saccharomyces cerevisiae. Biotechnol. Lett. 2008, 30, 1151-1161. [CrossRef]

25. Reis, V.R.; Bassi, A.P.G.; Cerri, B.C.; Almeida, A.R.; Carvalho, I.G.B.; Bastos, R.G.; Ceccato-Antonini, S.R. Effects of feedstock and co-culture of Lactobacillus fermentum and wild Saccharomyces cerevisiae strain during fuel ethanol fermentation by the industrial yeast strain PE-2. AMB Express 2018, 8, 23. [CrossRef]

26. Pelton, R. A review of antifoam mechanisms in fermentation. J. Ind. Microbiol. Biotechnol. 2002, 29, 149-154. [CrossRef] [PubMed]

27. Junker, B. Foam and its mitigation in fermentation systems. Biotechnol. Prog. 2007, 23, 767-784. [CrossRef] [PubMed]

28. Nielsen, J.C.; Senne de Oliveira Lino, F.; Rasmussen, T.G.; Thykær, J.; Workman, C.T.; Basso, T.O. Industrial antifoam agents impair ethanol fermentation and induce stress responses in yeast cells. Appl. Microbiol. Biotechnol. 2017, 101, 8237-8248. [CrossRef] [PubMed]

29. Stewart, G.G. Yeast Flocculation-Sedimentation and Flotation. Fermentation 2018, 4, 28. [CrossRef]

30. Blasco, L.; Viñas, M.; Villa, T.G. Proteins influencing foam formation in wine and beer: The role of yeast. Int. Microbiol. 2011, 14, 61-71. [PubMed]

31. Kordialik-Bogacka, E.; Ambroziak, W. Investigation of foam-active polypeptides during beer fermentation. J. Sci. Food. Agric. 2004, 84, 1960-1968. [CrossRef]

32. Kordialik-Bogacka, E.; Ambroziak, W. The relationship between polypeptides and foaming during fermentation. LWT Food Sci. Technol. 2007, 40, 368-373. [CrossRef]

33. Chen, Y.; Song, L.; Han, Y.; Liu, M.; Gong, R.; Luo, W.; Guo, X.; Xiao, D. Decreased proteinase A excretion by strengthening its vacuolar sorting and weakening its constitutive secretion in Saccharomyces cerevisiae. J. Ind. Microbiol. Biotechnol. 2017, 44, 149-159. [CrossRef] [PubMed]

34. Song, L.; Chen, Y.; Guo, Q.; Huang, S.; Guo, X.; Xiao, D. Regulating the Golgi apparatus sorting of proteinase A to decrease its excretion in Saccharomyces cerevisiae. J. Ind. Microbiol. Biotechnol. 2019, 46, 601-612. [CrossRef] [PubMed] 
35. Romano, P.; Suzzi, G.; Vannini, L. Relationship between foaming and flocculence in Saccharomyces cerevisiae wine strains. Colloids Surf. B Biointerfaces 1994, 2, 511-515. [CrossRef]

36. Palmieri, M.C.; Greenhalf, W.; Laluce, C. Efficient flotation of yeast cells grown in batch culture. Biotechnol. Bioeng. 1996, 50, 248-256. [CrossRef]

37. Verstrepen, K.J.; Klis, F.M. Flocculation, adhesion and biofilm formation in yeasts. Mol. Microbiol. 2006, 60, 5-15. [CrossRef]

38. Brückner, S.; Mösh, H.-U. Choosing the right lifestyle: Adhesion and development in Saccharomyces cerevisiae. FEMS Microbiol. Rev. 2012, 36, 25-58. [CrossRef]

39. van Mulders, S.E.; Christianen, E.; Saerens, S.M.; Daenen, L.; Verbelen, P.J.; Willaert, R.; Verstrepen, K.J.; Delvaux, F.R. Phenotypic diversity of Flo protein family-mediated adhesion in Saccharomyces cerevisiae. FEMS Yeast Res. 2009, 9, 178-190. [CrossRef]

40. Fichtner, L.L.; Schulze, F.; Braus, G.H. Differential Flo8p-dependent regulation of FLO1 and FLO11 for cell-cell and cell-substrate adherence of S. cerevisiae S288C. Mol. Microbiol. 2007, 26, 1276-1289. [CrossRef] [PubMed]

41. Dranginis, A.M.; Rauceo, J.M.; Coronado, J.E.; Lipke, P.N. A biochemical guide to yeast adhesins: Glycoproteins for social and antisocial occasions. Microbiol. Mol. Biol. Rev. 2007, 71, 282-294. [CrossRef]

42. Willaert, R.G. Adhesins of yeasts: Protein structure and interactions. J. Fungi 2018, 4, 119. [CrossRef]

43. Kraushaar, T.; Brückner, S.; Veelders, M.; Rhinow, D.; Schreiner, F.; Birke, R.; Pagenstecher, A.; Mösch, H.U.; Essen, L.O. Interactions by the fungal Flo11 adhesin depend on a fibronectin type III-like adhesin domain girdled by aromatic bands. Structure 2015, 23, 1005-1017. [CrossRef]

44. Zara, S.; Bakalinsky, A.T.; Zara, G.; Pirino, G.; Demontis, M.A.; Budroni, M. FLO11-based model for air-liquid interfacial biofilm formation by Saccharomyces cerevisiae. Appl. Environ. Microbiol. 2005, 71, 2934-2939. [CrossRef]

45. Douglas, L.M.; Li, L.; Yang, Y.; Dranginis, A.M. Expression and characterization of the flocculin FLO11/MUC1, a Saccharomyces cerevisiae mannoprotein with homotypic properties of adhesion. Eukaryot. Cell 2007, 6, 2214-2221. [CrossRef] [PubMed]

46. Goossens, K.V.Y.; Willaert, R. The N-terminal domain of the FLO11 protein from Saccharomyces cerevisiae is an adhesin without mannose-biding activity. FEMS Yeast Res. 2012, 12, 78-87. [CrossRef] [PubMed]

47. Goossens, K.V.; Stassen, C.; Stals, I.; Donohue, D.S.; Devreese, B.; De Greve, H.; Willaert, R.G. The N-terminal domain of the Flo1 flocculation protein from Saccharomyces cerevisiae binds specifically to mannose carbohydrates. Eukaryot. Cell 2011, 10, 110-117. [CrossRef]

48. Veelders, M.; Brückner, S.; Ott, D.; Unverzagt, C.; Mösch, H.U.; Essen, L.O. Structural basis of flocculin-mediated social behavior in yeast. Proc. Natl. Acad. Sci. USA 2010, 107, 22511-22516. [CrossRef]

49. Smukalla, S.; Caldara, M.; Pochet, N.; Beauvais, A.; Guadagnini, S.; Yan, C.; Vinces, M.D.; Jansen, A.; Prevost, M.C.; Latgé, J.P.; et al. FLO1 is a variable green beard gene that drives biofilm-like cooperation in budding yeast. Cell 2008, 135, 726-737. [CrossRef] [PubMed]

50. Verstrepen, K.J.; Jansen, A.; Lewitter, F.; Fink, G.R. Intragenic tandem repeats generate functional variability. Nat. Genet. 2005, 37, 986-990. [CrossRef] [PubMed]

51. Fidalgo, M.; Barrales, R.R.; Jimenez, J. Coding repeat instability in the FLO11 gene of Saccharomyces yeasts. Yeast 2008, 25, 879-889. [CrossRef]

52. Shimoi, H.; Sakamoto, K.; Okuda, M.; Atthi, R.; Iwashita, K.; Ito, K. The AWA1 gene is required for the foam-forming phenotype and cell surface hydrophobicity of sake yeast. Appl. Environ. Microbiol. 2002, 68, 2018-2025. [CrossRef]

53. Miyashita, K.; Sakamoto, K.; Kitagaki, H.; Iwashita, K.; Ito, K.; Shimoi, H. Cloning and analysis of the AWA1 gene of a nonfoaming mutant of a sake yeast. J. Biosci. Bioeng. 2004, 97, 14-18. [CrossRef]

54. Shimizu, M.; Miyashita, K.; Kitagaki, H.; Ito, K.; Shimoi, H. Amplified fragment length polymorphism of the AWA1 gene of sake yeasts for identification of sake yeast strains. J. Biosci. Bioeng. 2005, 100, 678-680. [CrossRef] [PubMed]

55. Blasco, L.; Veiga-Crespo, P.; Villa, T.G. FPG1, a gene involved in foam formation in Saccharomyces cerevisiae. Yeast 2011, $28,437-451$. [CrossRef] [PubMed]

56. Blasco, L.; Veiga-Crespo, P.; Sánchez-Pérez, A.; Villa, T.G. Clonning and characterization of the beer foaming gene CFG1 from Saccharomyces pastorianus. J. Agric. Food Chem. 2012, 60, 10796-10807. [CrossRef]

57. Argueso, J.L.; Carazzolle, M.F.; Mieczkowski, P.A.; Duarte, F.M.; Netto, O.V.; Missawa, S.K.; Galzerani, F.; Costa, G.G.; Vidal, R.O.; Noronha, M.F.; et al. Genome structure of a Saccharomyces cerevisiae strain widely used in bioethanol production. Genome Res. 2009, 19, 2258-2270. [CrossRef] [PubMed]

58. Babrzadeh, F.; Jalili, R.; Wang, C.; Shokralla, S.; Pierce, S.; Robinson-Mosher, A.; Nyren, P.; Shafer, R.W.; Basso, L.C.; de Amorim, H.V.; et al. Whole-genome sequencing of the efficient industrial fuel-ethanol fermentative Saccharomyces cerevisiae strain CAT-1. Mol. Genet. Genomics 2012, 287, 485-494. [CrossRef] [PubMed]

59. Wang, D.; Wang, Z.; Liu, N.; He, X.; Zhang, B. Genetic modification of industrial yeast strains to obtain controllable NewFlo flocculation property and lower diacetyl production. Biotechnol. Lett. 2008, 30, 2013-2018. [CrossRef] [PubMed]

60. Reynolds, T.B.; Fink, G.R. Bakers' yeast, a model for fungal biofilm formation. Science 2001, 291, 878-881. [CrossRef]

61. Ausubel, F.M.; Brent, R.; Kingston, R.E.; Moore, D.D.; Seidman, J.G.; Smith, J.A.; Struhl, K. Short Protocols in Molecular Biology, 3rd ed.; John Wiley \& Sons: New York, NY, USA, 1995.

62. Petracek, M.E.; Longtine, M.S. PCR-based engineering of yeast genome. Methods Enzymol. 2002, 350, 445-469.

63. Gietz, D.; St Jean, A.; Woods, R.A.; Schiestl, R.H. Improved method for high efficiency transformation of intact yeast cells. Nucleic Acids Res. 1992, 20, 1425. [CrossRef] [PubMed] 
64. Guerring, S.L.; Connelly, C.; Hieter, P. Positional mapping of genes by chromosome blotting and chromosome fragmentation. Methods Enzymol. 1991, 194, 57-77.

65. Stovíček, V.; Váchová, L.; Kuthan, M.; Palková, Z. General factors important for the formation of structured biofilm-like yeast colonies. Fungal Genet. Biol. 2010, 47, 1012-1022. [CrossRef]

66. Hope, E.A.; Dunham, M.J. Ploidy-regulated variation in biofilm-related phenotypes in natural isolates of Saccharomyces cerevisiae. G3 Gen. Genom. Genet. 2014, 4, 1773-1786. [CrossRef]

67. Kobayashi, O.; Yoshimoto, H.; Sone, H. Analysis of the genes activated by the FLO8 gene in Saccharomyces cerevisiae. Curr. Genet. 1999, 36, 256-261. [CrossRef]

68. Kuthan, M.; Devaux, F.; Janderová, B.; Slaninová, I.; Jacq, C.; Palková, Z. Domestication of wild Saccharomyces cerevisiae is accompanied by changes in gene expression and colony morphology. Mol. Microbiol. 2003, 47, 745-754. [CrossRef] [PubMed]

69. Ryan, O.; Shapiro, R.S.; Kurat, C.F.; Mayhew, D.; Baryshnikova, A.; Chin, B.; Lin, Z.Y.; Cox, M.J.; Vizeacoumar, F.; Cheung, D.; et al. Global gene deletion analysis exploring yeast filamentous growth. Science 2012, 337, 1353-1356. [CrossRef]

70. van de Velde, S.; Thevelein, J.M. cAMP-PKA and Snf1 signaling mechanisms underlie the superior potency of sucrose for induction of filamentation in yeast. Eukaryot. Cell 2008, 7, 286-293. [CrossRef]

71. Koschwanez, J.H.; Foster, K.R.; Murray, A.W. Sucrose utilization in budding yeast as a model for the origin of undifferentiated multicellularity. PLoS Biol. 2011, 9, e1001122. [CrossRef]

72. Koschwanez, J.H.; Foster, K.R.; Murray, A.W. Improved use of a public good selects for the evolution of undifferentiated multicellularity. eLife 2013, 2, e00367. [CrossRef]

73. Oud, B.; Guadalupe-Medina, V.; Nijkamp, J.F.; de Ridder, D.; Pronk, J.T.; van Maris, A.J.; Daran, J.M. Genome duplication and mutations in ACE2 cause multicellular, fast-sedimenting phenotypes in evolved Saccharomyces cerevisiae. Proc. Natl. Acad. Sci. USA 2013, 110, E4223-E4231. [CrossRef]

74. Ratcliff, W.C.; Fankhauser, J.D.; Rogers, D.W.; Greig, D.; Travisano, M. Origins of multicellular evolvability in snowflake yeast. Nat. Commun. 2015, 6, 6102. [CrossRef] [PubMed]

75. Chow, J.; Dionne, H.M.; Prabhakar, A.; Mehrotra, A.; Somboonthum, J.; Gonzalez, B.; Edgerton, M.; Cullen, P.J. Aggregate filamentous growth responses in yeast. $m$ Sphere 2019, 4, e00702-e00718. [CrossRef]

76. Rodrigues-Prause, A.; Sampaio, N.M.V.; Gurol, T.M.; Aguirre, G.M.; Sedam, H.N.C.; Chapman, M.J.; Malc, E.P.; Ajith, V.P.; Chakraborty, P.; Tizei, P.A.; et al. A case study of genomic instability in an industrial strain of Saccharomyces cerevisiae. G3 Gen. Genom. Genet. 2018, 8, 3703-3713. [CrossRef] [PubMed]

77. Hope, E.A.; Amorosi, C.J.; Miller, A.W.; Dang, K.; Heil, C.S.; Dunham, M.J. Experimental evolution reveals favored adaptive routes to cell aggregation in yeast. Genetics 2017, 206, 1153-1167. [CrossRef]

78. Liu, H.; Styles, C.A.; Fink, G.R. Saccharomyces cerevisiae S288C has a mutation in FLO8, a gene required for filamentous growth Genetics 1996, 144, 967-978. [CrossRef]

79. Fidalgo, M.; Barrales, R.R.; Ibeas, J.I.; Jimenez, J. Adaptive evolution by mutations in the FLO11 gene. Proc. Natl. Acad. Sci. USA 2006, 103, 11228-11233. [CrossRef]

80. Zara, G.; Zara, S.; Pinna, C.; Marceddu, S.; Budroni, M. FLO11 gene length and transcriptional level affect biofilm-forming ability of wild flor strains of Saccharomyces cerevisiae. Microbiology 2009, 155, 3838-3846. [CrossRef]

81. Halme, A.; Bumgarner, S.; Styles, C.; Fink, G.R. Genetic and epigenetic regulation of the FLO gene family generates cell-surface variation in yeast. Cell 2004, 44, 405-415. [CrossRef]

82. Voordeckers, K.; De Maeyer, D.; van der Zande, E.; Vinces, M.D.; Meert, W.; Cloots, L.; Ryan, O.; Marchal, K.; Verstrepen, K.J. Identification of a complex genetic network underlying Saccharomyces cerevisiae colony morphology. Mol. Microbiol. 2012, 86, 225-239. [CrossRef] [PubMed]

83. Holmes, D.L.; Lancaster, A.K.; Lindquist, S.; Halfmann, R. Heritable remodeling of yeast multicellularity by an environmentally responsive prion. Cell 2013, 153, 153-165. [CrossRef]

84. Scherz-Andersen, K.; Bojsen, R.; Sørensen, L.G.R.; Weiss, M.; Nielsen, L.M.; Folkesson, A.; Regenberg, B. Genetic basis for Saccharomyces cerevisiae biofilm in liquid medium. G3 Gen. Genom. Genet. 2014, 4, 1671-1680.

85. Rupp, S.; Summers, E.; Lo, H.J.; Madhani, H.; Fink, G. MAP kinase and cAMP filamentation signaling pathways converge on the unusually large promoter of the yeast FLO11 gene. EMBO J. 1999, 18, 1257-1269. [CrossRef]

86. Kuchin, S.; Vyas, V.K.; Carlson, M. Snf1 protein kinase and the repressors Nrg1 and Nrg2 regulate FLO11, haploid invasive growth, and diploid pseudohyphal differentiation. Mol. Cell. Biol. 2002, 22, 3994-4000. [CrossRef] [PubMed]

87. Kayacan, Y.; Van Mieghem, T.; Delvaux, F.; Delvaux, F.R.; Willaert, R. Adaptive evolution of industrial Brewer's yeast strains towards a snowflake phenotype. Fermentation 2020, 6, 20. [CrossRef] 